\title{
Thinking about Ecological and Culture Education in College Take example of Guangxi Eco-engineering Vocational and Technology College
}

\author{
Li-Na LI, Wen-Bang WEI, Jia-Cheng $\mathrm{AN}^{\mathrm{a}, *}$ \\ GuangXi Eco-engineering Vocational and Technology College, GuangXi LiuZhou, China \\ a447284003@qq.com \\ ${ }^{*}$ Corresponding author
}

Key words: vocational college, culture education, thinking

\begin{abstract}
Educating high qualified professional person is the vocational college goal, so called high qualified personnel is with professional knowledge, ability of getting used to society and accordingly ideas. It is much necessary to search for ways to talk about vocational college education function. The writer hereby is thinking the route through connotation, function and realization and combine real example from Guangxi Eco-engineering vocational and technical college.

Under the status elite higher education and mass coexistence, nationalization and internationalization of common development, to teach knowledge alone can `t adapt to the era of rapid development speed and quality of personnel training needs. Chairman Xi Jinping, stress for youth in the May Fourth conversation that "firming ideals and beliefs, studying skills and creation, determined to work hard, temper noble character," the five requirements. Then explore of the educational function to the university culture, cultural education universities seek to achieve the path is very necessary.
\end{abstract}

\section{Innovation of college education}

Culture is a combined body of knowledge system, ideas, survival method evolved from human's social practice. The college culture is also born by culture development, is all wealth in spirit and material, including material, rules, action and spirit, in which spirit is the core. The usually talked college culture in fact is spiritual culture tradition.

Campus culture is the soul of a school development to unite the people, showing the image of the school, improving school degree important manifestation of civilization. Construction of campus culture on students' life and values creep summer side produce a far-reaching impact of this effect which is often unmatched by any programs (such as Peking University, Sing Hua door - known as "gate Culture").

Today, the construction of campus culture requires us to make the creative intent expressed on inner beauty, skill and slowly move up a static environment, so a static environment produces cultural beauty, ready to dialogue with those, which we set up a static environment meaning of culture. Knowledge learned in school you really basically forget, but the school that tree, the school with the iconic things you never forget, and this iconic tree or something (including the old classrooms, auditoriums, etc.), there must be the soul, inspire the formation and direction of my struggle, which is why we want to establish when a static environment of culture, to form its soul, which is very important.

Education must take advantage of dynamic and static two cultures to pleased, what we say to form a nurturing environment, or is circumstance education. When we interpret an educational and cultural way when it also gives the intangible, invisible, distant thing, but it reflected the spirit, ideas and feelings, so you motivated, patriotic, love, humility, responsibility, integrity, gratitude, compassion. 


\section{Function of college education}

\section{Value guidance}

University insisting the correct values in the training process of students is the most important function. University orientation and development strategy, regulations, personnel training objectives, teaching system, academic standards, teaching style, curriculum, teaching methods and other factors, are based on the core values of this set.

\section{Emotional excitation function}

When one set of values that give the overall recognition of university teachers and students, it is likely to become a binder which can put together their own members gather from all aspects, have a strong cohesion, solidarity and promoting strength, bursting out of the group and personal powerful energy, so that it can for the mission and reputation of the school's college of courage, innovation (for example: "May Fourth" spirit inspired the majority of young people to fight for freedom, democracy, the Lei Feng spirit inspire millions of people to do it. "good deeds, "Zhang Side spirit inspires us to" serve the people ", Yan'an Spirit inspires us to" seek truth from facts, hard work, "etc.).

\section{Value recognition feature of Guangxi Eco-engineering vocational and technical college}

University culture always affects value judgments of teachers and students, teaching philosophy, habits and ways of thinking. As a social organizations, universities should be all members of their culture within the organization are able to consciously observe and practice things. Such as: in the whole society are vigorously advocate and practice the socialist core values, when the integrity of the Chinese nation considered itself to be a code of conduct and morality, has been given a wealth of content, to further heritage, rich in cultural education, eco-School faculty dormitory area set up in a "good faith Coin take food service point", the integrity of the dishes take inspiration from college a few years ago to see a farmers often pick vegetables to sell, if the college set up a shopping point without staff care, but also to facilitate faculty. In fact, the "good coin to take food service point" setting, should influence the value judgments of teachers and students, teaching philosophy, habits and ways of thinking.

\section{Cultivate emotional function}

The reason of university of influence that can't be replaced is its cultural influence, impact of culture on college students with profound potential and durability. Ecology yard as "Dragon" spots, from a distance, a few tens of meters "Big Dragon" vividly presented in front. In fact, the attraction is more than ten years ago, under the guidance of teachers with a garden of knowledge, the college road side planting plants "fishtail Kwai", after years of cultivation and professional care, without the trim, natural formation of leaf fish Kwai like dragon scales, "leading" is the banyan tree forest canoe. <Ci Hai> said, "The dragon is a kind of ancient legends have scales makes the rain and clouds miraculous animal." In Chinese culture, the dragon has an important position and influence. Down for thousands of years, the dragon has penetrated every aspect of Chinese society has become a cultural cohesion and accumulation. This "dragon" formation, represents the harmony between man and nature, also told the students Chinese culture and professional skills of the organic combination. While these are not necessarily the teachers able to teach, but it certainly is dependent on the rich cultural atmosphere among university.

\section{University of cultural education to achieve path}

Modern education is fully educating, all aspects of education and educating people throughout the process. Starting point of all the modern university is individuals, and fully mobilize the person's initiative to promote the comprehensive development and to meet human development needs, is people-oriented must adhere to. University campus is a high level and high-level humanized nature, together show in the natural also cultural characteristics. Universities must create a strong cultural 
atmosphere, enhance scientific connotation, encouraging college students to improve science literacy and humanities character.

\section{Building a harmonious educational environment, creating a good atmosphere for education}

Harmonious campus environment is important to all teachers and students for teachers and students to achieve better services, provided the comprehensive services. Strengthening the construction of the campus environment, focusing on teaching building, student dormitory, library and campus greening and beautifying facilities and equipment in the spiritual and cultural connotation construction, with the school campus culture and dissemination of communication channels to render school healthy, motivated and harmonious environment. Entering into Guangxi Ecological Engineering Vocational and Technical College which is located in Guangxi Liuzhou is as likely walking in a broad botanical gardens, wide campus, valuable trees abound, dazzling yet refreshing, a pool of water, surrounded by the campus, the lotus bloom in the lake, drift with bursts of fragrance. Classroom, under the shade of a tree, students are concentrating on learning. The entire campus is full of vitality. Motto stone, Tai Chi, Big Bird, derivative, Master Stone, Dragon, walls of Three Character Classic is the highlight of the campus. Enter college gate, we can see a sail-shaped boulder (motto stone), positive carved the words "cultivating talents as growing trees, unite the behavior and knowledge" eight eye-catching characters, is the College motto, [cultivating talents as growing trees, explain] tree: Metaphor personnel training is a permanent solution. Also said that personnel training is not easy. Source from pipe • Right to repair":. "one year`s planning, nurturing Tree Valley; decade, plant trees; lifelong ahead, education people". Unity of knowledge and action is the main object conform, known means scientific knowledge, the behavior refers to the practice of the unity of human knowledge and action." cultivating talents as growing trees, unite the behavior and knowledge " highlight the educational philosophy of Guangxi Vocational and Technical College of Ecological Engineering, concise school characteristics which are green with universities, the Academy's 50 years of history and tradition heritage, ecological Vocational-man half-century crystallization of practice, covering the spirit and values of the pursuit of college, reflecting the College hosted the heavy historical responsibility and the atmosphere. The back of the boulder is engraved with Mao Zedong's Cursive "Yi Fan Feng Shun", meaning the post-graduate students who work, study and life go well.

\section{Strengthen the main channel of the classroom and teachers should play a leading role}

Arrange major courses reasonably to reflect teaching art. The emotional education and education should be combined in teaching. To reach students' psychological care through emotional education, as"manage and teach according to personal characteristics" Teachers as the perpetrators of emotional education should strengthen self-education to accomplish the goals. Emotion plays a role in education, and not just "Teach and preaching". All educators should love and care students and think on students' site. One word by professor JiaCheng An that: It is just a person who only loves his kid, but a sage if loves other's."

In addition to regular education, the main focus of ecological College faculty "ecological environment, green university" theme, "Beautiful ecology. Harmonious Campus" activities, campus scenery exhibition, "the most beautiful ecological person", with "Thanksgiving alma mater "as the theme music culture on campus plaza quality development sharing activities, Including teachers and skill games, arts campus culture festival, family of teachers, students' employment entrepreneurial activity etc. Carried out by calligraphy, painting, essay, eco-photography, exhibitions and columns to form a network of "ecological environment, green university" and other topics related to the quality of development activities and sharing the results of activities to achieve real industrial research institute in conjunction with interactive, gathering union improves the students and faculty staff attention on the construction of campus culture, and further build a harmonious campus, beautiful ecology, human ecology concept formation, while teachers and students to improve the sense of ownership, improve well-being of teachers and students. Further enhance the cultural 
heritage institute, highlighting the school characteristics.

\section{Carry out effective management education work}

Culture can provide a good system for college fair, orderly educational environment that provides specifications for the daily behavior of college students, college students in favor of the formation of the value of identity, that is, "to develop education." Colleges and universities according to the new requirements of the development, its own reality, the development of relevant management system, it can not only protect the interests of students, but also to strengthen its initiative to make all-round development of students as possible. Especially with student learning and life are closely related systems, such as reward and punishment system, school management system, etc., these new system management system to respect the vital interests of students, to better serve the students become adults. Another example is in the campus, classroom suspension celebrity portraits, famous aphorism, artwork, motto, establish school history exhibition rooms, schools honor promenade, outstanding graduates style exhibitions, both noble and create a healthy atmosphere of the cultural landscape, more provide teachers and students to learn from efforts to strength and the way forward.

\section{Epilogue}

As for colleges and universities` highly qualified teaching, in addition to training people teaching reform, we should also strengthen the construction of university campus culture, highlight the educational function of the university campus through cultural influence on students to help students form a correct outlook on life, values, worldviews, so that students develop individual freedom, eventually prompting them to be adults, and then taught, and finally achieve their goals in life.

Students establish a correct outlook on life, noble moral character, health, ae sthetic improvement, all subject to the influence and impact of positive campus culture. Continuously strengthening the construction of a harmonious campus environment and constantly improving the level of teaching management educators form a combined management situation and to give full play of the leading role of the teachers to the initiative of students, so that they are fully unassuming personality, fully guaranteed dominant position of students. College education quality in order to get this constantly improve, to run from college has specialties. Campus Culture Construction in Guangxi Ecological Engineering Vocational and Technical College is relying on the advantages of the school is the University of Guangxi University Green to "a matter of a scene with one stone and classical gardens of the iceberg" of cultural connotation further build and form a unique campus culture and eco-philosophy for cultivating human by culture stone (stone culture) and rare plants (tree culture), enlightening people by classical gardens and then teachers and students will formed "ecological" concept.

\section{Reference}

$[1]<$ Opinions on Further Strengthening and Improving Ideological and Political Education> - China Daily News peter

[2] An Jia cheng , $2013<$ School personnel administration line enterprise social construction and practice of co-culture system $>$ 